\title{
Theology, Religious Studies and the Secular Academy: Rhetoric and the Control of Meanings ${ }^{1}$
}

\author{
TIMOTHY FITZGERALD \\ University of Stirling
}

\begin{abstract}
The debates among academics over whether Religious Studies belongs within Faculties of Theology, the Social Sciences or The Humanities is a distraction from a more fundamental issue, which is the pervasive and largely unquestioned assumption that religious experiences, practices and institutions are universally distinct in kind and essentially separate from non-religious ones. Theologians and non-theologians alike have contributed to constructing a modern discourse on 'religion' and 'religions' that tacitly embeds its distinction from 'non-religious' or 'secular' practices. What is assumed as a commonplace is best understood as a rhetorical construction, which historically has had the ideological function of subverting a much older understanding of 'religion' that inhibited class mobility and the growth of capitalist institutions. The most notable feature of the study of 'religions' lies in the tacitly distinct and embedded 'secular' or non-religious ground from which the study is assumed to be conducted. It was this wider rhetoric that made possible a basic part of the warp and woof of modern consciousness, the non-religious state and the ubiquitous arena of 'secular politics'.
\end{abstract}

Keywords: theology, religion, politics, secular, economics, state, sacred and profane

\section{Theology and Religious Studies}

At a recent conference at Oxford on the relations between Theology and Religious Studies, we heard from a number of speakers that Theology and

\footnotetext{
${ }^{1}$ My thanks to Veikko Anttonen for inviting me to participate in the symposium 'The Study of Religion as a Discipline' in Turku on 26 March 2007, from which occasion the present article has been developed. Thanks also to Veikko for his patience with a somewhat unwieldy structure of argumentation, caused by my attempt to bring out the interdisciplinary and wide-ranging implications not only of 'religion' but of the categories from which it is separated (and therefore connected). Thanks to Balu Balagangadhara, Esther Bloch, Marianne Keppens and all the organizers and participants of the 'Rethinking Religion in India' conference held in Delhi 21-24 January 2008. The ideas in this article have been tested by many conversations. Though not ostensibly about India, the problematic application of the category 'religion' has been very much in mind. Finally, thanks to an anonymous reader for her or his useful critical comments, which have led me to further clarify some parts of the argument.
} 
Religious Studies are not clearly separable, theoretically or methodologically. ${ }^{2}$ Neither domain is clearly definable since both are amorphous, diverse, with porous borders, over-lapping theoretically and methodologically. Both are normative, permeated by metaphysics; for example, the Christocentric Trinitarian Theology is not more problematic than the modern idea of 'religion' as a generic universal that incarnates as 'religions'. For the relationship between 'religion' and the countable specific instances of 'religions' to be found at all times and in all places can seem like a universal mystical essence or noumenon that manifests in different phenomenological circumstances.

In the United Kingdom, Theology and Religious Studies departments are often, but not always, a single administrative unit. Whether or not they actually share an administrative unit, the nineteenth-century 'science of religion' was partly a theological project, in the direct sense that the Christian theological presuppositions of providential monotheism were rife in its foundations and in the attitudes of its earliest theorists, for example Cornelius Petrus Tiele, Elements of the Science of Religion (1898). While claiming, though sometimes ambiguously, the neutral ground of a science, many of the most important and influential 'founders' of the study of religion had a theological agenda: either of the kind that imagined Christianity, especially Protestant Christianity, as a mark of superior rationality and civility, or of the more liberal ecumenical kind, which imagined 'religions' as different paths to the one God who created and governs the world. I suggest that the crucial point is that these writers powerfully influenced the emergent discourse on 'religions' as objects of scientific knowledge, and thus tacitly constructed the objective, neutral, 'non-religious' ground of the modern secular. ${ }^{3}$

On the other hand, not all the progenitors of 'religions' as objects of analysis were crypto-theologians. Scholars such as Edward B. Tylor, Sir James G. Frazer, Herbert Spencer, Émile Durkheim and Max Weber were either agnostic or atheist, and took a stand that questioned the rationality

\footnotetext{
${ }^{2}$ Organised by the Subject Centre for Philosophical \& Religious Studies, UK on 6 July 2006.

${ }^{3}$ These Euro-American theorists were also assisted in the construction of 'world religions' by the indigenous elites of colonized polities. This is a significant point because arguably the rhetorical construction of new discourses on religions is only fully intelligible in the context of colonialism (Asad 1993; Chidester 1996; King 1999; Fitzgerald 2000; 2007a).
} 
of all 'faith'. ${ }^{4}$ Whatever the subtlety (or ambiguity, or lack of clarity) of their theoretical intentions, it is hard to deny that Durkheim's The Elementary Forms of the Religious Life (1912), or Weber's Sociology of Religion (1922), have had a massive effect in embedding the assumption that religion constitutes a universal and distinctive kind of experience and practice that in one way or another can be analytically separated from non-religious experiences and practices. ${ }^{5}$ They all in one way or another equate 'religion' with either 'the sacred' or the 'supernatural', and equate - I think uncritically - 'secular' scientific or technical practices with 'the profane'. ${ }^{6}$ In this process, the modern religion-secular dichotomy has come to be equated with the sacred-profane, and appears to be in the nature of things, the same in all cultures and in all historical periods.

Part of the purpose of this article is to suggest how the usages and nuances of terms such as religion, secular, sacred, profane, state, politics, civil and many others have changed historically, and the implications of such changes. Typical modern usages constitute conscious or unconscious transformations to long-standing conventional usages, and such transformed

\footnotetext{
${ }^{4}$ The anonymous reader argued 'I think [...] that the author might actually find an ally rather than an adversary in Weber; for instance, Weber, I suspect, would heartily agree with this central claim that, "What we need to bring into view is that there is no religion as such."' And he goes on to say that 'Weber, for instance, in his "'Objectivity' in the Social Sciences..." (1907[?]), expressed concerns about both the reification of abstractions ("religion" included) and about objectivity.' I would certainly not want to make Weber an adversary, given the range and depth of his knowledge and his theoretical fecundity. However, arguably this point indicates ambiguity in his work. Further, whatever his intentions might or might not have been, his Sociology has been appropriated in such a way that it has immeasurably strengthened the illusion that religions, religious experiences and religious institutions are either things with a distinctive nature that actually exist in the world, or alternatively validly neutral concepts useful and indeed unavoidable for scientific description and analysis. In effect, and whatever he may or may not have intended, his sociology of religion has become a powerful discursive landmark in the invention of religion. This latter point applies in different but comparable ways to the theories of Tylor, Frazer, Durkheim and a variety of other writers who have been enlisted as ancestors for the modern study of religion.

${ }^{5}$ For just two of the multiple possible examples of the contemporary uncritical deployment of these rhetorical assumptions, see Lincoln (1996) and Halliday (2005). For a critique see Fitzgerald 2006, 2007b.

${ }^{6}$ Durkheim stands out for ambiguity. In my view the most interesting and powerful theoretical drive of the Elementary Forms is towards understanding the formation of classification systems and the generation of dominant categories by collective practices. This has the contrary effect of de-essentializing and dissolving the universality of the religion-secular binary. Mary Douglas picks up this creative and critical trend with great force and imagination. But the overall effect of Durkheim's definition of religion and his positivistic reification of societies as organisms is to anchor religion in the sacred, the secular in the profane, and to embed the idea of religious studies as a science with a distinct object. If Durkheim can save us, he was himself one of the people who led us into the confusion.
} 
meanings have facilitated and reflected wider significant transformations in power. Yet despite the paradigmatic revolution that has occurred approximately since the seventeenth century, the rhetoric of persuasion has generated an illusion of continuity, as though such English-language terms as 'religion' or 'politics' or 'secular' simply and intuitively correspond to those prevalent in earlier centuries. Even more than this, English language terms are assumed to apply across the board to universal aspects of human life and consciousness. This illusion, produced by the magical power of words, turns out to be a paradoxical truth: we Europhones are duped by our own rhetorical constructions.

\section{Seventeenth-Century Origins of the Invention of Religion(s) and the Secular}

The nineteenth-century progenitors of the study of religions, whatever their theoretical relation to theology, were themselves an important stage in a process going back to the seventeenth century, when the modern discourse on the essential separation of religion and politics (as well as religion and science) was arguably first clearly and powerfully stated. It was in the seventeenth century that the identification of 'religion' with 'church', and of 'politics' with 'state', was first rhetorically appropriated, in English at least. This new dichotomy - that religion was a private and personal affair, that had nothing essentially to do with the magistrate or the public domain - was inherent in the call for their constitutional 'separation'. This change in the meaning of words, which I return to in more detail in a later section of this article, became progressively more embedded, especially in the North American bills of rights, culminating in the US Constitution.

This change was not only in the meaning of the terms 'religion' and 'church'; it involved other significant changes as well. The word 'politics', as a noun demarcating a (non-religious) domain, was virtually invented in the seventeenth century ('economics' came later, in the late eighteenth or early nineteenth century). And by the mid-nineteenth century the term 'secular', which earlier had referred mainly to the priesthood and to some civil functions, had come to acquire the nuance of 'non-religious' (in modern terms, who ever heard of a 'non-religious' priesthood?).

There was another semantic shift, however, at least as important as these. This was the equation of the 'sacred' with 'religion' and the 'profane' with the 'secular', these dichotomies in turn becoming aligned with other binaries, such as church and state. I want to claim that there is a profoundly different 
logic in the use of these terms, which has been obscured by powerful writers, including Eliade and Durkheim: a confusion which has served to consolidate the idea of 'religions' as objects of 'secular' study, and yet paradoxically to transform discourses on religion into ideological constructs of modernity.

\section{Seventeenth Century: Filmer, Locke and Penn}

In the mid-seventeenth century, Sir Robert Filmer (1588-1653) thought he knew what religion meant - Christian Truth which encompassed the church-state; ${ }^{7}$ or, in a different formula, in language commonly used, the Commonweal or Commonwealth. This was ideologically constituted by a fixed, hierarchical, patriarchal order, which embodied Christian Reason. But in A Letter Concerning Toleration, John Locke (1632-1704) said Filmer was wrong; religion really meant something quite different. He makes a clear distinction between two domains: ${ }^{8}$ on the one hand religion as a personal Faith in a providential God and a future life, juridically expressed as a private, non-political right to form voluntary associations or churches; on the other hand a civil magistracy or domain of politics which (unlike voluntary 'religious societies' $)^{9}$ has the right to use force to impose law and order, a State to which we all owe allegiance. Locke posited that this distinction between personal religion (faith and conscience) and public obedience to the state corresponds to other dualisms which are in the nature of things, such as the distinction between the inner and the outer: between the soul or mind, which is spiritual and concerned with salvation, and the body, which is physical and subject to the public disciplines of political order. He argued that this distinction is in the nature of things, a nature which had become perverted by centuries of enforced conformity to the Catholic church-state. The truth is supposedly witnessed in the Biblical distinction between this world and the world to come, as in Christ's saying, 'Give unto Caesar the things that are Caesar's, and unto God the things that are God's' (Matt. 22:21). If one knows how to read the Bible rightly, one can see the

\footnotetext{
7 I write 'church-state' deliberately. As I have argued in my book Discourse on Civility and Barbarity (2007b), and as I go on to argue more briefly here, Religion as Christian Truth encompassed both church and state; the distinction between the ecclesiastical and the temporal or civil authorities was not a distinction between 'religion' and the secular state in the modern sense. 8 ' [...]I esteem it above all things necessary to distinguish exactly the Business of Civil Government from that of Religion, and to settle the just Bounds that lie between the one and the other' (Locke 1689, 8).

${ }^{9}$ One can clearly see a stage in the reification of 'societies' into nouns, essentially defined as 'religious' and tacitly distinguished from non-religious civil society (Locke 1689, 17). See Bossy on the tendency to reification (1985, 170-1).
} 
original and true meaning of 'religion', which had too often been covered up by centuries of ecclesiastical control of the polity. ${ }^{10}$

Though Locke was an Anglican his background was in Calvinism and trade, and he was motivated partly by his ambiguous support for Dissent and the cause of Toleration. He also developed interests in the colonies of North America and was appointed by the King as Secretary to the Board of Trade, which superintended colonial interests. In his many talents and interests, Locke exemplifies the seventeenth-century English Enlightenment. He belonged with Newton and other natural philosophers to the Royal Society. He developed an influential empiricist epistemology, which is one of the ways in which the world became objectified as a self-sufficient system of corpuscular matter occupying 'container' time and space. Philosophically Locke is famously a dualist. The objectivity of scientific knowledge presupposed an observing mind receiving impressions from an external world. He was not a modern capitalist (the modern theory of capitalism was only in the process of emergence), but he was one of a generation who understood the power in trade that Dissent could engender, for example in the case of Holland (see Aaron 1955, 293). He also conceived of property rights in ways that favored what would in other contexts be judged the theft of the lands of indigenous peoples (Pagden 1998, 40-7). He was one of a number of writers who had a powerful influence on the development of individual North American state bills of rights and constitutions, culminating in the U.S. Constitution - which might be described as a sacred secular Enlightenment document which guarantees civil rights, of which personal religion is one.

Yet the meanings of the terms 'secular' and 'civil' were themselves in transition, contested, and did not yet have discursive dominance in England in the modern sense until much later (see the discussion below). The contested meanings of these fundamental terms may explain why Locke himself was simultaneously a member of the conservative Anglican Church-State who believed in the Christian scheme of Providence, and an inspiration to Dissenters, Unitarians, Deists and the North American framers of liberal, Enlightenment constitutions. His discourses actually reflect, shape, and in a sense constitute a duality which in hindsight appears as a transition from 'non-modern' to 'modern'. Modern writers use such words as 'religion' or 'secular' as though they have essential meanings, which can be uncovered where they have been historically confused; as though we can say that the referents of, and relationships between, terms such as 'religion' or 'politics'

10 For a detailed discussion of Locke and other preachers and philosophers who had similar views as Locke, such as William Penn and Benjamin Hoadly, both of whom were influential in the development of American Constitutionalism, see Fitzgerald 2007b. 
are universal in time and place, even though the precise relationship between the two may not always have been as clear as it ought to be. However, when in retrospect we see the disputations about the meanings of these terms in the seventeenth and eighteenth century, we can see that one persuasive discourse, that of Religion as encompassing Christian Truth, shared in different ways by Catholics, Lutherans, Calvinists and Anglicans, was being contested by a newer discourse that appealed to specific constituencies: new and growing colonial interests that were transforming the sources of wealth and prestige, and a scientific method that was constructing new sources of authority for knowledge and 'truth'. Retrospectively we can see a significantly new imaginaire, which virtually turned the older meanings of words on their head.

It is in this longer-range historical context that I want to argue that nineteenth and twentieth century formulations of the study of 'religion' have something significant in common with earlier writers, which may be more important than the question whether the practitioner of the science of religion is personally a believer or not, or theoretically pro- or anti-theology. More recent theorists have inherited, reproduced and finessed an ideological discourse which has, through various forms of rhetorical persuasion, repressed (though not eradicated, for they are still operational) earlier meanings and promoted those that have a greater affinity with emergent power relations. To invent what, variously, Friedrich Max Müller (1823-1900) and Cornelius Petrus Tiele (1830-1902) referred to in their famous Gifford Lectures as The Science of Religion, or what Weber called The Sociology of Religion, or what Durkheim called The Elementary Forms of the Religious Life, is - whatever their conscious theological or non-theological intentions might now be construed to be - to add their weight to the modern reifying discourse of the essential separation of two distinct domains: on the one hand religions, faiths or spiritualities, on the other hand the secular, scientific, objective ground from which they may be named, listed, described, and compared. A non-religious position from which to view the world and make scientific judgments about it provides a position from which 'religion', 'religions', 'religious' experiences and 'religious' practices may be viewed with neutrality or objectivity, thus disguising their rhetorical and persuasive construction. From this discursive standpoint the secular position is tacitly one of superiority. Modern writers across the humanities who claim to be describing and comparing religions and religious experiences are uncritically reproducing these ideological categories, under the illusion that they are ahistorical and neutral. 
This is an entirely different understanding of religion from an encompassing Christian Truth, which, far from being a possible object of observation ('a religion') has historically been considered to be that which makes any observation or consciousness possible at all! In the context of this new reifying discourse, which by the end of the nineteenth century was wellestablished in England, even the professing Christian can step outside the framework which gives all life meaning and view it as merely one item amongst others (although ultimately the superior model)..$^{11}$ The momentousness of this difference in meaning does not inhibit contemporary scholars from talking about 'religion' as though its essential meaning (apart from one or two definitional quibbles) is obvious to all speakers of the language. I want to draw attention to the way theologians, sociologists, anthropologists ${ }^{12}$ and more problematically phenomenologists ${ }^{13}$ have contributed to constructing a discourse on 'religion' and 'religions' that tacitly embeds its distinction from 'non-religious' or 'secular' practices. What is assumed as a commonplace (the essential distinction between religion and the secular, or between religious practices such as praying or preaching and secular or non-religious practices such as giving a dinner party or voting in elections) was really a rhetorical act of persuasion which aimed at subverting a much older understanding of these words, and which followed the contours of a wider Anglophone and more widely Europhone modern ideology which had been developing since the seventeenth century. ${ }^{14}$ Arguably the most significant aspect of this development was not the construction of 'religionsas-such', but of the non-religious secular which that construction makes possible; it was this wider rhetoric that made possible the warp and woof of modern consciousness, including as one facet the idea that religions are essentially voluntary acts of faith, instigated by a sui generis experience of

\footnotetext{
${ }^{11}$ It is the confusion between these two logically distinct discourses that may partly explain the ambiguity that runs through some of the writers I am considering.

${ }^{12}$ I should add psychologists too, including William James. See Carrette and King in their Selling Spirituality (2004).

${ }^{13}$ I say 'more problematically' because the anonymous reader has pointed out to me that phenomenologists do not, in most cases, share a confidence in a neutral, objective standpoint. I would respond by saying that, in that case, this loosely defined group may ambiguously be straddling two historically different understandings of 'religion'. This is an interesting point, which I admit I cannot satisfactorily confront in this short article.

${ }^{14}$ To avoid an infinite regress I have suggested that the earliest clear formulation of the idea that religion is essentially different from politics can be found in the writings of William Penn and John Locke from around 1680. Readers may find earlier statements of this idea, but it was in the post-Reformation period, in England at least, that the distinction between a privatised religion and a public non-religious state is advocated by Dissenters and Non-Conformists, many of them with American colonial interests.
} 
the supernatural, and resulting in voluntary associations of like believers, which in turn can be studied, described and compared from a 'secular' standpoint. The 'secular', like 'religion' and 'religions', is widely assumed to be simply there, part of the natural order of things. But the 'secular' (like 'nature', 'natural' and 'matter') is itself a problematic rhetorical construction which is fundamentally dependent on the discourse on 'religion' and 'religions'.

What we need to recognise is that there is no religion as such. There is a powerful discourse of 'religion as such', but this discourse implies 'religion as something distinct from the secular', something sui generis and essentially different from, though having problematic relations with, non-religious experiences, institutions and practices. This implication becomes explicit in dualistic discourses such as the natural and the supernatural, the inner and the outer, the soul and the body, the future eternal life and the present historical reality, and in many modern constitutional separations of religion from the state. These modern meanings are in radical contrast to the much older rhetorical discourse of Religion as encompassing Christian Truth. The relationship between the two is a profoundly important illusion, if that is not too paradoxical a way of putting it. The common element between proand anti-theology students of 'religion' is that by transforming 'religion' into multiple objects which can be studied 'objectively' from a secular standpoint, or as sui generis aspects of experience, the secular standpoint itself is validated by becoming embedded into the order of things. Michael Cahn refers to the 'tendency of rhetoric to constitute itself as the agent of a pre-existent nature' and its art lying in strategies whereby 'rhetoric constitutes itself as a discipline and simultaneously makes us forget the rhetorical conditions of its disciplinary existence' (Cahn 1993, 79-81). Analogously, modern rhetoric, deriving from influential thinkers whose ideas had an elective affinity with growing sources of powerful interest, has constituted religion as having a 'pre-existent nature', and has made us forget 'the rhetorical conditions' of its historical birth. I would go further and argue that the secular standpoint, understood as non-religious in the sense either of neutrality or of reductive hostility towards 'religion', is actually made imaginable by the claimed existence of religions themselves. The crucial thing for the researcher is to be provided with the illusion that one occupies a position of superior natural rationality that conforms to the 'real' world. However many assurances we may receive from the contemporary purveyors of a modern myth, the primary ideological function of 'the study of religions' in claiming to give us knowledge of things in the world called 'religions' (which turn out to 
be rhetorical fictions anyhow) is to convince us that they exist. By being convinced of the existence of religions in the world, guaranteed by some putative type of special experience, we can in turn make the even more important assumption that we occupy a neutral, objective non-religious standpoint in line with common sense. This has come to constitute normal consciousness in modern liberal capitalist states.

\section{The Secular as Multiple Discursive Domains}

We do not need to know or agree what we mean by 'religion' to proceed with its rhetorical deployment. By arguing about the definition of religion, we further embed the assumption that religion is a universal reality about which we will one day finally achieve proper knowledge. Abstract definitional disputes about 'religion' are strategies that divert attention away from its rhetorical construction and more deeply embed the illusion that religion per se is a substantive aspect of human life and consciousness, and that religions are ubiquitous (whatever difficulties we may have in finessing their precise characteristics). In this way a non-religious, natural, material world that conforms to positivistic science ${ }^{15}$ to the dictates of markets and to what politicians and accountants deem as common sense is ritually embedded in self-evident factuality. Definitional issues, like arguments about 'reductionism', are not real disputes but useful distractions from the more critical question of how and why both 'religion' and the non-religious secular have been rhetorically constructed as a dichotomy. This is the same issue for both Theology and Religious Studies, as it is also for the rest of the Humanities and Social Sciences. Furthermore, this ought to be (I hope to persuade the reader) the fundamental issue for the study of 'religion'.

One could pose the concept of secularity made available by the religionsecular dichotomy in terms of scientific objectivity and neutrality, in other words as a cognitive issue. However, while an assumption about rationality runs like a thread through discourses on the secular, it is not constructed in terms of scientific knowledge alone. If we deconstruct this grand category further, we find that it has been made up historically of a number of different discursive domains, which when combined account for our everyday, banal, common sense consciousness, both collectively and individually. One of these discursive domains is the secular State and politics. Another is economics. These are themselves modern rhetorical inventions rather than

\footnotetext{
${ }^{15}$ Some twentieth-century science, however, surely challenges such positivistic constructions of matter, time and space.
} 
the discoveries of scientific objective reason. But they have all been imagined historically as standing in contradistinction to 'religion'.

The rhetoric of the modern capitalist State, embedded in constitutional forms as non-religious in the sense of being neutral towards religion, strives to license religion (or 'faith', or 'spirituality') as a private, non-political right of individuals, while protecting the State from religion. This is arguably the most powerful locus of their mutual, symbiotic, and indeed parasitic relationship. I argue that what we have here is not merely a re-arrangement of the relationship between pre-existent 'entities', but the invention by rhetoric of essentialized domains; these domains never existed before the modern configuration began to get big by feeding on its elective affinity with powerful interests in Dissent and the colonies. It is in this sense analogous to the point that Gellner has made about modern nationalism and nations: 'Nationalism is not the awakening of nations to self-consciousness: it invents nations where they do not exist' (quoted in Anderson 1991, 5; see Gellner 1983).

I am arguing that 'religions' and the 'secular State', which are fundamental features of the modern imaginaire, never existed before modernity. In a significant sense they construct modernity and have a crucial function in the legitimization of capitalism and the uncritical promotion of technology and consumerism as the dominant value system (Carrette \& King 2004). Another source of the ecumenical construction 'world religions' were the Europeanized indigenous elites of non-western polities, either colonized or fearing colonization, who collaborated with the missionaries, civil servants, administrators and orientalist scholars. These world religions are most famously Hinduism, Buddhism, Islam (or Mohammedanism, as it used to be miscalled), Sikhism, Zoroastrianism, Confucianism, Shintoism, Taoism and so on ad infinitum (for a good account of these processes, especially in the context of India, see King 1999). Many of these colonized elites also helped to construct modern secular nation states with written constitutions as the focus for anti-colonial liberation movements, thus assisting Euro-America (not always willingly) by embedding the modern category of 'religions' and their distinction from 'the secular' into the very shape of the new independent nation states and their rhetorical legitimations. Yet, contradictorily, the purveyors of these essentialized ideologies sometimes stubbornly refuse to remain confined to the voluntary and the private, but forge powerful bonds with the legitimation of the nation state itself, thus defying the modern rhetoric of 'religion' and 'religions' that brought them into being. 


\section{Meanings of the English Word 'Religion' in Historical Perspective}

In his biography of Thomas More, Peter Ackroyd gives us a good picture of life and consciousness in a Christian world in which the idea of the 'non-religious' (as distinct from the relatively profane) would have been inconceivable. Discussing More's morally ambiguous involvement in the downfall of the Duke of Buckingham, who was beheaded for treason in 1521, and the subsequent appropriation of his lands, Ackroyd says about More:

Yet he was not averse to profiting from some, if not all, of these enviable possessions. [...] He lived in the spiritual as well as the secular world. In the former he practised individual prayer and penitence, while in the latter he derived his identity from the social hierarchy in which he found himself. One was a question of private, the other of customary, ritual. To be a good Christian, in both worlds, required obedience and the fulfilment of obligations - which included providing an inheritance for his descendants. One may be labelled piety, and the other decorum; but they are both aspects of the same religious civilization. (Ackroyd 1998, 215.)

The two worlds to which Ackroyd refers - the 'spiritual' and the 'secular' - were not equivalent to the modern essentialized distinction between the religious and the non-religious. One might instead say that his duty to his descendants was relatively more profane in the scale of things than his duty to his King; and that his duty to his King was relatively more profane in the scale of things than his duty to the Pope; or that his duty to the Pope was relatively more profane than his duty to Christ. But still, all are sacrosanct as duties, for all are in the final analysis duties to God. Similarly one might say that the celibate life of the secular priest was relatively more profane than the life of the religious, especially the strict orders whose renunciation went beyond celibacy. But this is profoundly different from the modern constitutional and academic discourse on religions and the secular state.

When, where and how did the modern English-language discourse of 'religion' and 'religions' arise? As I have already suggested, a good starting point is early modern society in England, from where the English language discourse on Religion mainly spread, especially to North America. ${ }^{16}$ From America it spread in many directions, not least towards France at the time

\footnotetext{
${ }_{16}$ I do not mean to imply that this diffusion took place from England alone; people also went to the American colonies for example from Scotland and Ireland. In the seventeenth century, however, it was mainly England.
} 
of the Revolution, but also towards South America in the 1820s (Bailyn 2002; 1967), and towards non-European polities such as Japan. This final section is intended to suggest, in rather summary form, how differently words were used in comparison with today. By this means I hope to underpin my claim that the religions, religious experiences and religious practices of modern discourse, far from being self-evident aspects of all human history, or neutral descriptive concepts, need to be understood as parts of an ideological configuration, a paradigm that has rhetorically disguised its modern origins and has become embedded as an unquestionable and unavoidable representation of the real world of common sense.

\section{Religion as Christian Truth}

For many centuries Religion meant Christian Truth. The opposite of Religion was not 'the secular', but Superstition. In the powerful Roman Catholic Church discourse, significant aspects of which were incorporated into the new Anglican church-state, Religion as Christendom encompassed the whole of reality. What was outside Religion could not properly exist: falsehood, ignorance, evil, all destined for hell, for a kind of limbo or non-being. True, there were disagreements about what constituted Christian Truth, but few doubted that the truth about life and death was revealed through Christ, the Bible and the Church authorities. And few doubted that Christian Truth encompassed all aspects of life, including what we have subsequently separated out as 'the state' and as distinct spheres of political, economic or scientific practice.

\section{The 'Religious' as a Status}

The term 'religious' (as distinct from 'the religious') is difficult to find in texts before the seventeenth century. It was generally only used in the sense of 'the religious' monks, nuns, friars; also 'the religious houses', e.g., monasteries, convents, and abbeys. 'The religious' was a status within Christendom. These were abolished in England and other Protestant countries, such as Holland and some German states, though the term still persists in such contexts as Catholicism and high Anglicanism. At around the same time Catholicism was condemned by Protestants as 'superstition', along with 'Mahometanism' (Islam) and Paganism. Thus in one early seventeenth-century text (Purchas 1626) I found the Protestant expression 'the superstitious religious', a deliberate Protestant satirical play on words to describe the Catholic monastic orders. But this play is also an indication of a significant shift in nuance. 
However, it should be noted that the adverb 'religiously' seems to have a very ancient sense, possibly going back to the Roman religio (see Balangangadhara 1994; King 1999) which indicates the performance of duties with care and attention regardless of any further, additional and later Christian monotheistic preoccupation with doctrinal orthodoxy. Thus, while most English-Latin dictionaries and concordances will consistently define 'religion' as 'belief in God', they usually also include another quite different sense of the performance of a practice 'religiously', such as 'faithfully, strictly, exactly, conscientiously, scrupulously' (OED online edition). This meaning decouples the concept from the over-determined Protestant associations of 'religious practice' with 'worship of God', and shifts the semantic weight to ritual practices in a wider sense. The religious dedication of a craftswoman to her craft is thus not different in kind from the religious dedication of a Buddhist renouncer to meditation. The populist choreography and democratic liturgy behind the media-framed swearing-in of a new President of the United States is presumably as faithful, strict, exact, conscientious and scrupulous in its attention to detail as the performance of any Vatican ceremony.

\section{The 'Secular' as a Status}

For centuries the 'secular' referred either to 'secular priests' or to civil powers such as the Courts. None of these were non-religious in the modern sense of 'secular'. Priests and Kings were sacred and anointed by God through the powers of the Church; the secular or civil Courts, which were distinguished not from the Religious Courts but from the Ecclesiastical Courts, were encompassed by Christian Truth which defined their ends. They served Christ, and co-operated with the ecclesiastical courts in punishing heretics. The 'civil' did not have the nuance of the modern 'secular', since even for Luther and Calvin the civil was only relatively profane, was encompassed by Christian Truth, and served the purposes of God. It is significantly different in this context to say that the civil courts of Christendom were separated from the ecclesiastical courts, and to say that the civil was separated from religion. These two distinctions, when placed in their proper context, have different meanings. Even following the demise of the power of Ecclesiastical courts the procedures of the modern civil courts are highly ritualized, solemn, and invested with a dignity and importance that can be called sacred or sacrosanct without any strain on the ordinary use of language - just as we can say today that the conscientious judge religiously interprets each case according to evidence and precedence. 


\section{Christian Truth as Commonweal}

Religion understood as Christian Truth was frequently expressed in terms of a sacred social order - I would prefer to use the anthropological term ritual order - called the Commonweal. This was based on an analogy with the human body. It was a holistic metaphor. Every limb is necessary for the whole, but some limbs are more important than others: the monarch as the heart, his learned advisors as the head, laborers as the feet, great soldiers as the arms. This was a powerful metaphor, a utopian discourse widely disseminated and fixing hierarchy in the order of things, that is to say God's order. Everyone is born into a specific degree, station and vocation. Duty is sacred. Thus the ritual order of England was sacralised. By serving one's master, one served God. By serving the whole Body Politic, one served the divine well-being and harmony of God's Providence.

\section{Analogy between God, King and Father}

The Commonweal, based on the analogy with the human body, was also an analogy for the Creation: As God is the Dad and Progenitor of All, so the King is the Lord and Head of the Commonweal, and the Father is the Head of the family. The family at the level of the Commonweal included church and state, ecclesiastical and temporal, bishop and prince, the spiritualty and the commonalty, and all orders and degrees. All were encompassed by Christian Truth. This was the meaning of Religion. This metaphor legitimated male authority, patriarchy, paternalism, obedience, duty to one's superiors as part of the natural order. The relatively profane tasks, such as labouring, were still sacralized in official rhetoric as God-given duties. The relative profanity of aspects of the world did not amount to the modern 'secular' as something dichotomized and separated from religion. It is therefore in my view necessary to keep the idea of the profane separate from the modern essentialized idea of the secular as the non-religious.

\section{The State as an Abstract Entity with its own Nature}

The distinction between Church and State was not the modern one, nor was it the same as the modern distinction between religion and politics. Both Church and State were encompassed by Religion, meaning Christian Truth. The historian of political theory Quentin Skinner, in The Foundations of Modern Political Thought (1978), argues that the first conception of the State in something like the modern sense was articulated by Jean Bodin in around 1570. By this he means that Bodin conceived of the State as an abstract entity 
in and for itself, and as distinguishable from the older organic idea of the Commonwealth. This, however, cannot be the end of the story, because we do not yet have an idea of 'religion' as something in and for itself. And I argue that until 'religion' has also been separated off into a separate, distinct, essentialized domain, we cannot have the modern idea of the secular nonreligious State. We are still looking at a process, the rhetorical construction of modern categories through new discourses which suppress their own recent origins and which claim to be as old as the hills. The illusion of primordial continuity embeds categories in the mythological nature of things.

\section{Politics as 'Non-religious' and Separated from 'Religion': From Where?}

The other side of this question is: where does the idea of politics as essentially non-religious come from? The term 'politics' in English occurs before the seventeenth century, but infrequently. A much more usual term was 'politic'. Politic (like the word 'civil') did not refer to a domain separated from 'religion'. The politic body was the well-ordered (Godly) Commonweal. Any action could be described adverbially as 'politic' if it was appropriate, fitting, useful, and conducive to harmony and good order. It had a nuance also of diplomacy. Henry VIII and his ministers used it to refer to the Church rituals of which they approved. This term did not become a discourse of modern politics as secular in the sense of 'separated from and neutral towards religion' until there also existed a discourse on religion as a discrete domain separate from the State. There is a historical transition from the adjectival 'politic' to the noun 'politics' especially around the later seventeenth century.

Two examples of influential late-seventeenth century rhetorical reformulations of the meaning of 'religion' and the invention of modern 'politics' as a distinct domain were William Penn and John Locke. William Penn, founder of Pennsylvania and writer of early liberal constitutions, urged on his readers the following:

Religion and Policy, or Christianity and Magistracy, are two distinct things, have two different ends, and may be fully prosecuted without respect one to the other; the one is for purifying, and cleaning the soul, and fitting it for a future state; the other is for Maintenance and Preserving of Civil Society, in order to the outward conveniency and accommodation of men in this World. A Magistrate is a true and real Magistrate, though not a Christian; as well as a man is a true and real Christian, without being a Magistrate. (Penn 1680, 4.) 
Here we can clearly see a distinctly new rhetoric of the essential difference between religion and policy, a word which is at this time beginning to become interchangeable with politics. For Penn is rhetorically constructing a notion of religion as private, individual, concerned with the next life, and 'policy' or 'magistracy' as concerned with a distinct public domain of civil society.

Similarly John Locke, ${ }^{17}$ in his A Letter Concerning Toleration (London, 2nd edition, 1689), argued:

I esteem it above all things necessary to distinguish exactly the Business of Civil Government from that of Religion, and to settle the just Bounds that lie between the one and the other. If this be not done, there can be no end put to the Controversies that will be always arising, between those that have, or at least pretend to have, on the one side, a Concernment for the Interest of Mens Souls, and on the other side, a Care of the Commonwealth. [...] The Commonwealth seems to me to be a Society of Men constituted only for the procuring, preserving, and advancing of their own Civil Interests. Civil Interests I call Life, Liberty, Health, and Indolency of Body; and the possession of outward things, such as Money, Lands, Houses, Furniture, and the like. (Locke 1689, 8-9.)

The duty of the Civil Magistrate 'by the impartial Execution of equal Laws' is to defend through the fear of punishment and the possession of force, 'the civil interests of his Subjects'.

Locke seeks to persuade his readers - and himself - that

the whole Jurisdiction of the Magistrate reaches only to these civil Concernments [...] it neither can nor ought in any manner to be extended to the Salvation of Souls (Locke 1689, 9).

[A]ll the Power of Civil Government relates only to Men's Civil Interests; is confined to the care of the things of this World; and hath nothing to do with the World to come. [...] A Church I [...] take to be a voluntary Society of men, joining themselves together of their own accord, in order to the publick worshipping of God, in such a manner as they judge acceptable to him, and effectual to the Salvation of their Souls. (Locke 1689, 13.)

\footnotetext{
${ }_{17}$ My argument seems to converge in some respects with that of Jakob de Roover and S. N. Balagangadhara (forthcoming in the journal Political Theory).
} 
This is a free and voluntary society; no-one can inherit religion from their parents in the way that 'Temporal Estates' are inherited, it is purely individual, voluntary, to do with inner belief and salvation. If the individual makes an error of judgement he is free to leave that church or sect and join another. We can see clearly here the rhetorical construction of 'religion' and 'politics' (also referred to as civil society or the magistracy) as essentially different in terms of ends, organisation and functions. Furthermore, one is private and the other public. Both Penn and Locke influenced the development of state charters and constitutions.

Benjamin Hoadly was a radical Anglican bishop who was frequently cited and quoted in American radical pamphlets, especially his The Original and Institution of Civil Government, Discuss'd (London, 2nd edition, 1710a), and The Measures of Submission to the Civil Magistrate Consider'd. In Defence of the Doctrine. Deliver'd in a Sermon Preach'd before the Rt. Hon. the Lord Mayor, Aldermen, and Citizens of London, Sept. 29, 1705 (1710b). In these writings, Hoadly pursues a distinction between religion and the polity which is close to the kind being argued by Penn and Locke. For example, he directly attacks what he calls the Patriarchal Scheme of Government, referring implicitly to Filmer (1991), whom Locke critiqued in his first Treatise (1988). Bernard Bailyn says in his The Ideological Origins of the American Revolution (1967) that Hoadly 'was widely held to be one of the most notable figures in the history of political thought' in the colonies (Bailyn 1967,37). This is another indication of the importance of the colonization of America in the formation and clarification of this modern ideological construct. Locke, Penn and Hoadly were among the most often cited and quoted theorists in North America in the eighteenth century, and influenced the state charters, the bills of rights and the various constitutions, all of which fed into the U.S. Constitution of 1789/90. Bailyn, after reviewing specific instances of the influence of the Constitution globally, concludes that

In the generations that have followed, that influence has remained pervasive - not merely in the design of specific constitutions but mainly and increasingly, as America's power has grown, in its embodiment of established western values (Bailyn 2002, 25).

\section{The Power of Rhetoric}

I have frequently used the term 'rhetorical constructions'. Richard Roberts and J. M. M. Good in their The Recovery of Rhetoric: Persuasive Discourse and Disciplinarity in the Human Sciences (1993) argue that 
[R]hetoric has played a central part in the formation, development and legitimation of the emerging human sciences. [...] If we are to understand the present-day classifications and hierarchies of the various disciplines in the human sciences, then it is essential to understand their rhetorical constitution. (Roberts \& Good 1993, 4.)

One of the key points they make about rhetoric, in concordance with their contributor Michael Cahn (1993, 61-84), is that rhetoric not only constructs disciplines and domains of discourse but also disguises their origins in ways that make them appear as commonplaces, as part of the common order of things. I suggest that writers in the late seventeenth and early eighteenth centuries such as Locke, Penn and Hoadly were rhetorically constructing a new binary: one which, when embedded in the radical constitutional thinking of eighteenth century America, formed the basis for two new essentialized domains, 'religion' and 'politics', and 'religion' and 'the state'. The rhetorical origins of these distinctions, while well known, were also strategically forgotten, because they became naturalized in Enlightenment reason, along with a range of other essentialized dichotomies: soul and body, spirit and matter, supernature and nature, rational science and irrational or non-rational faith. The modern academic discipline of Religious Studies, and the much wider academic discursive deployment of 'religion' and 'spiritualities', was formulated within this hegemonic discourse. Developments in Theology - Protestant Theology in particular - both resisted and collaborated. Yet at the same time there is an older discourse of the Church-State, which was hegemonic long before the modern binary became progressively articulated in the context of colonialism and the nation state as it was emerging as a distinct, abstract, rational, non-religious entity. This confusion of discourses operates to obscure the assumptions about the rhetorical construction, not of 'religion' alone, as though that category refers to something of and in its own right, but simultaneously 'religion' in problematic relation to 'state', 'politics', and other modern categories of 'secular' rationality such as 'economics'. 
Bibliography

Aaron, R. I.

1955 (1937) John Locke. 2nd Edition. Oxford: Clarendon Press.

\section{Ackroyd, Peter}

1998 Thomas More. London: Chatto \& Windus.

\section{Anderson, Benedict}

1991 Imagined Communities: Reflections on the Origin and Spread of Nationalism. Revised Edition. London and New York: Verso.

Asad, Talal

1993 Genealogies of Religion: Discipline and Reasons of Power in Christianity and Islam. Baltimore, Md., \& London: John Hopkins University Press.

\section{Bailyn, Bernard}

1967 The Ideological Origins of the American Revolution. Cambridge, Mass.: Harvard University Press.

2002 American Constitutionalism: Atlantic Dimensions. Caroline Robbins Lecture of 2001. London: Institute of United States Studies, University of London.

\section{Balagangadhara, S. N.}

1994 'The Heathen in His Blindness': Asia, the West, and the Dynamic of Religion. Leiden: E. J. Brill.

\section{Bossy, John}

1985 Christianity in the West, 1400-1700. Oxford: Oxford University Press.

\section{Cahn, Michael}

1993 The Rhetoric of Rhetoric: Six Tropes of Disciplinary Self-Constitution. - R. H. Roberts \& J. M. M. Good, The Recovery of Rhetoric: Persuasive Discourse and Disciplinarity in the Human Sciences, 79-80. Charlottesville \& London: University Press of Virginia.

\section{Canny, Nicholas (ed.)}

1998 The Origins of Empire, Oxford: Oxford University

\section{Carrette, Jeremy \& Richard King}

2004 Selling Spirituality: The Silent Takeover of Religion. London: Routledge.

\section{Chidester, David}

1996 Savage Systems: Colonialism and Comparative Religion in Southern Africa. Charlottesville: University of Virginia Press. 


\section{Filmer, Sir Robert}

1991 (1680?) Patriarchy and Other Writings. Johann P. Sommerville (ed.). Cambridge: Cambridge University Press.

\section{Fitzgerald, Timothy}

2000 The Ideology of Religious Studies. New York \& Oxford: Oxford University Press.

2006 Bruce Lincoln's Theses on Method: Antitheses. - Method E Theory in the Study of Religion, 18 (4): 392-423.

2007a Religion and the Secular: Historical and Colonial Formations. [Editor]. London: Equinox.

2007b Discourse on Civility and Barbarity: A Critical History of Religion and Related Categories. New York: Oxford University Press.

\section{Gellner, Ernest}

1983 Nations and Nationalism. Ithaca, N.Y.: Cornell University Press

\section{Halliday, Fred}

2005 'A matter of power, not religion', interview with Adam Holm. - LSE Magazine, Winter 2005: 6-7.

\section{Hoadly, Benjamin}

1710a The Original and Institution of Civil Government, Discuss'd. 2nd edition. London.

1710b The Measures of Submission to the Civil Magistrate Consider'd. In Defence of the Doctrine. Deliver'd in a Sermon Preach'd before the Rt. Hon. the Lord Mayor, Aldermen, and Citizens of London, Sept. 29, 1705

\section{King, Richard}

1999 Orientalism and Religion: Postcolonial Theory, India and the Mystic East. London: Routledge.

\section{Lincoln, Bruce}

1996 Theses on Method. - Method $\mathcal{E}$ Theory in the Study of Religion 8: 225-7.

\section{Locke, John}

1689 A Letter Concerning Toleration. 2nd edition. London.

1988 (1690) Two Treatises of Government. - Peter Laslett (ed.), Cambridge Texts in the History of Political Thought. Cambridge: Cambridge University Press.

\section{O'Gorman, Frank}

1997 The Long Eighteenth Century: British Political and Social History, 16881832. London: Arnold.

\section{Pagden, Anthony}

1998 The Struggle for Legitimacy and the Image of Empire in the Atlantic to c.1700,-Nicholas Canny (ed.), The Origins of Empire, 34-54. Oxford: Oxford University Press. 


\section{Penn, William}

1680 The Great Question to be Considered by the King, and this approaching Parliament, briefly proposed, and modestly discussed: (to wit) How far Religion is concerned in Policy or Civil Government, and Policy in Religion? Microfiche found in National Library of Scotland, Edinburgh.

Purchas, Samuel

1626 (1613) Purchas, His Pilgrimage; or, Relations of the World and the Religions Observed in All Ages. London.

Roberts, R. H. \& J. M. M. Good

1993 The Recovery of Rhetoric: Persuasive Discourse and Disciplinarity in the Human Sciences. Charlottesville \& London: University Press of Virginia.

Roover, Jakob de \& S. N. Balagangadhara

Forthcoming John Locke, Christian Liberty and the Predicament of Liberal Toleration. - Political Theory, 2008.

\section{Skinner, Quentin}

1978 The Foundations of Modern Political Thought, vol. 2, The Age of Reformation. Cambridge: Cambridge University Press.

\section{Stack, Trevor}

2006 A Higher Ground: the secular knowledge of objects of religious devotion. - Timothy Fitzgerald (ed.), Religion and the Secular: Historical and colonial Formations, 47-69. London: Equinox.

\section{Tiele, Cornelius Petrus}

1898 Elements of the Science of Religion, [Part I. Morphological; Part II: Ontological], (The Gifford Lectures, 1896-1898.) Edinburgh: William Blackwood and Sons. 